\title{
Mutations in Caprine DGAT1 and STAT5A Genes were Associated with Milk Production Traits
} —-Combined Effects of DGAT1 and STAT5A Genes on Milk Yield and Fat

\author{
Xiaopeng An, Jinxing Hou, Haibo Zhao, Chunmei Zhu, Quanmei Yan, Yuxuan Song, \\ Jiangang Wang, Binyun Cao \\ College of Animal Science and Technology, Northwest A\&F University, Yangling, Shaanxi P.R. China \\ Email: caobinyun@yahoo.com.cn
}

Received 2012

\begin{abstract}
In this study, polymorphisms of the DGAT1 and STAT5A genes were detected in 528 individuals from Xinong Saanen and Guanzhong goat breeds by PCR-RFLP, PCR-SSCP and DNA sequencing methods. Three allelic variants were identified: DQ380250: g.407_408insC, AJ237937: g.6798C $>\mathrm{T}$ and g.6852C $>\mathrm{T}$ in both breeds. At g.407_408insC locus, the frequencies of $\mathrm{C}_{1}$ allele were $0.79-0.85$, and frequencies of $C_{2}$ allele were $0.21-0.15$. At g.6852C $>T$ locus, frequencies of $C_{3}$ allele were $0.70-0.72$, and frequencies of $T_{3}$ allele were $0.30-0.28$. Compared with goats with $C_{1} C_{1}$ and $C_{3} C_{3}$, those with $C_{1} C_{2}$ and $C_{3} T_{3}$ genotypes had significant effects on milk yield and fat percentage $(\mathrm{P}<0.05)$, respectively. The result showed that does with $\mathrm{C}_{1} \mathrm{C}_{1} \mathrm{C}_{3} \mathrm{~T}_{3}$ and $\mathrm{C}_{1} \mathrm{C}_{2} \mathrm{C}_{3} \mathrm{~T}_{3}$ had higher milk yield than those with $\mathrm{C}_{1} \mathrm{C}_{2} \mathrm{C}_{3} \mathrm{C}_{3}(\mathrm{P}<0.05)$. In addition, the combined effect of $\mathrm{C}_{1} \mathrm{C}_{2} \mathrm{C}_{3} \mathrm{~T}_{3}$ on milk fat percentage was the highest in comparison with other combination genotypes $(\mathrm{P}<0.05)$.
\end{abstract}

Keywords: Dairy Goat; Milk Production Traits; Fat Percentage; Pedigree

\section{Introduction}

Milk production traits are of fundamental importance in livestock production and the related economy [1]. Selection aimed at increasing the frequency of alleles with a positive effect on a given trait was initiated by geneticists [2]. Meanwhile, variation of either candidate genes for production traits or linked genetic markers has informed the basic biology of milk production and composition, and encouraged the use of gene for marker assisted selection (MAS) in livestock [3]. In general, identifying and validating genetic markers for milk production traits is the initial and crucial step to establish a MAS system.

Diacylglycerol acyltransferases (DGATs) catalyse the final step of the triacylglycerol (TAG) biosynthesis of the Kennedy pathway [4]. Two genes (DGAT1 and DGAT2) have been shown to encode DGATs. Both genes encode membrane-bound proteins, with no sequence homology to each other [5]. DGAT1 gene was the first identified gene encoding a protein with DGAT activity [6]. Diacylglycerol acyltransferase1 (DGAT1) was identified as one underlying quantitative trait locus (QTL) for milk production traits in the centromeric region of the bovine chromosome $14[7,8]$. The signal transducers and activators of transcription (STATs), a family of transcription factors, mediate the actions of a variety of peptide hormones and cytokines [9]. STAT5, also known as mammary gland factor (MGF), was discovered initially as a PRL-induced transcription factor [10]. It is a key intracellular mediator of prolactin signalling and can activate transcription of milk protein genes in response to prolactin $[10,11]$. STAT5 exists in two isoforms - A and B, which differ by a few amino acids in the carboxylic end of the protein molecule; separate genes code both of them [12]. In cattle, the STAT5A and STAT5B genes were located close to each other (within $40 \mathrm{~Kb}$ ) at chromosome 19 [13]. Antoniou et al. (1999) described two SSCP variants of the gene fragment that encodes the SH2 domain in bovine STAT5A protein [14]. Brym et al. (2004) detected a new SNP (A/G) located in the intron 9 of STAT5A gene at position 9501 [15]. The aim of this study was to investigate SNPs in DGAT1 and STAT5A genes, and analyze the combined effect of DGAT1 and STAT5A genes on milk production traits to provide the theoretical basis for goat breeding.

\section{Materials and Methods}

\subsection{Animals and Genomic DNA Isolation}

Blood samples were obtained from 528 goats belonging to two breeds: Xinong Saanen (SN, n=285) and Guanzhong (GZ, $\mathrm{n}=243$ ). They were reared in Qianyang county and Zhouzhi county of Shaanxi province, respectively. Health, fertility and milk recording was carried out by dairymen and veterinarians. Data was recorded in winter and spring parturitions of 2008 to 2011. Milk yields from first to third lactation were standardized to 300 days in milk. For milk analysis, a milk sample was taken from each animal once per month throughout the third lactation, sampling first at least 20 days after parturition to exclude the risk of contamination with colostrum. Goats were milked twice a day at constant intervals and a $10 \mathrm{ml}$ sample from each milking session was mixed for the analysis. Milk constituents (protein, lactose and fat) were determined with an ultrasonic S60SEC milk analyzer (Milkotronic Company, Nova Zagora, Bulgaria). Five milliliters blood per goat were collected asepti- 
cally from the jugular vein and kept in a tube containing anticoagulant ACD (citric acid:sodium citrate:dextrose - 10: 27: 38). The genomic DNA was extracted from white blood cells using standard phenol-chloroform extraction protocol [16].

\subsection{PCR Amplification}

According to bovine DGAT1 and STAT5A genes (GenBank accession no. AJ318490 and AJ237937), fourteen pairs of primers were designed to amplify goat DGAT1 and STAT5A genes. Pairs of primer 1 and 2 are shown in Table 1. Other primer pairs with no polymorphism detected in their amplification regions are not listed. The $25 \mu \mathrm{L}$ volume contained $50 \mathrm{ng}$ genomic DNA, $12.5 \mu \mathrm{L} 2 \times$ reaction mix (including $500 \mu \mathrm{M}$ dNTP each; $20 \mathrm{mM}$ Tris - HCl; pH 9; $100 \mathrm{mM} \mathrm{KCl;} 3 \mathrm{mM}$ MgCl2 ), $0.5 \mu \mathrm{M}$ of each primer, and 0.5 units of Taq DNA polymerase. The cycling protocol was $5 \mathrm{~min}$ at $95^{\circ} \mathrm{C}, 35$ cycles of denaturing at $94^{\circ} \mathrm{C}$ for $30 \mathrm{~s}$, annealing at $59^{\circ} \mathrm{C}$ (primer pair 1) and $63^{\circ} \mathrm{C}$ (primer pair 2) for $30 \mathrm{~s}$, extending at $72^{\circ} \mathrm{C}$ for $30 \mathrm{~s}$, with a final extension at $72^{\circ} \mathrm{C}$ for $10 \mathrm{~min}$.

\subsection{SNP Genotyping and Sequencing}

The SSCP analysis of PCR products of primer pair 2 refers to An et al. (2011) [17]. In addition, PCR products $(5 \mu l)$ of primer pair 2 were mixed with $1 \mu 110 \times$ buffer, 3 U Eco81 I (TaKaRa, Dalian, China) and $3.5 \mu$ sterilized ddH2O, and then incubated for $1.5 \mathrm{~h}$ at $37^{\circ} \mathrm{C}$. Digested products were subjected to PAGE $(80 \times 73 \times 0.75 \mathrm{~mm})$ in $1 \times$ TBE buffer and constant voltage $(110 \mathrm{~V})$ for $1.5 \mathrm{~h}$. After the polymorphisms were detected, amplicons representing unique banding patterns were sequenced in both directions in ABI 377 DNA analyzer (Applied Biosystems, Foster, California, USA) and the sequences were analyzed with DNAstar software (version 7.1) and Blast in NCBI (National Center for Biotechnology Information).

\subsection{Statistical Analysis}

The allelic frequencies, heterozygosity (He) and polymorphism information content (PIC) were calculated using Cluster-analysis software (version 1.2). Milk production traits analyzed in the current study included milk yield, milk protein, lactose and fat. Statistical analysis was performed using univariate analysis in the general linear model procedure of SPSS 16 statistical software. The linear model applied was:

$Y_{\mathrm{iknjlm}}=\mu+G_{\mathrm{i}}+B_{\mathrm{k}}+P_{\mathrm{n}}+N_{\mathrm{j}}+(P G)_{\mathrm{ni}}+S_{\mathrm{l}}+E_{\mathrm{iknjlm}}$ (model 1) where $Y_{\text {iknjlm }}$ is the trait measured on each of the iknjlm ${ }^{\text {th }}$ animal, $\mu$ is the overall population mean, $G_{\mathrm{i}}$ is the fixed effect associated with the $\mathrm{i}^{\text {th }}$ genotype, $B_{\mathrm{k}}$ is the fixed effect associated with the $\mathrm{k}^{\text {th }}$ breed, $P_{\mathrm{n}}$ is the fixed effect associated with the $\mathrm{n}^{\text {th }}$ parity, $N_{\mathrm{j}}$ is the fixed effect associated with the $\mathrm{j}^{\text {th }}$ number of kids born, $(P G)_{n i}$ is the interaction between the $n^{\text {th }}$ parity and $i^{\text {th }}$ genotype. $S_{1}$ is the random effect associated with the $\mathrm{l}^{\text {th }}$ sire, and $E_{\mathrm{iknjlm}}$ is the random error. The combined effects of DGAT1 and STAT5A genes on milk production traits were analyzed with the following model:

$Y_{\text {iknjlm }}=\mu+C_{\mathrm{i}}+B_{\mathrm{k}}+P_{\mathrm{n}}+N_{\mathrm{j}}+(P C)_{\mathrm{ni}}+S_{\mathrm{l}}+E_{\mathrm{iknjlm}}($ model 2) where $Y_{\mathrm{iknjlm}}, \mu, B_{\mathrm{k}}, P_{\mathrm{n}}, N_{\mathrm{j}}$ and $S_{\mathrm{l}}$ are the same as shown for model $1, C_{\mathrm{i}}$ is the fixed effect associated with the $\mathrm{i}^{\text {th }}$ combination genotype, and $(P C)_{n i}$ is the interaction between the $n^{\text {th }}$ parity and $\mathrm{i}^{\text {th }}$ combination genotype.

\section{Results}

\subsection{SNPs Identification and Genotypes}

The bands of different genotypes are shown in Figure 1A and 1B. Comparisons among these nucleotide sequences of difference genotypes indicated that one base insertion (g.407_ 408insC, GenBank accession no. JF781126) was detected in the

Table 1. Primer sequences and information on goat DGAT1 and STAT5A genes.

\begin{tabular}{cclccc}
\hline \multirow{2}{*}{ Gene } & Primer & \multicolumn{1}{c}{ Sequence (bp) } & Ta $\left({ }^{\circ} \mathrm{C}\right)$ & Amplicon & Product size (bp) \\
\hline \multirow{2}{*}{ DGAT1 } & P1 & $\begin{array}{l}\text { F: 5-AGGAACTCGGAGTCCATCAC-3 } \\
\text { R: 5- TGAAGGCCCAGAGGCGGAAC-3 }\end{array}$ & 59 & \multirow{2}{*}{ Exon 14-16 } & \multirow{2}{*}{328} \\
\multirow{2}{*}{ STAT5A } & P2 & $\begin{array}{l}\text { F: 5- CTGCAGGGCTGTTCTGAGAG-3 } \\
\text { R: 5- TGGTACCAGGACTGTAGCACAT-3 }\end{array}$ & 63 & Exon 7 & \multirow{2}{*}{215} \\
\hline
\end{tabular}

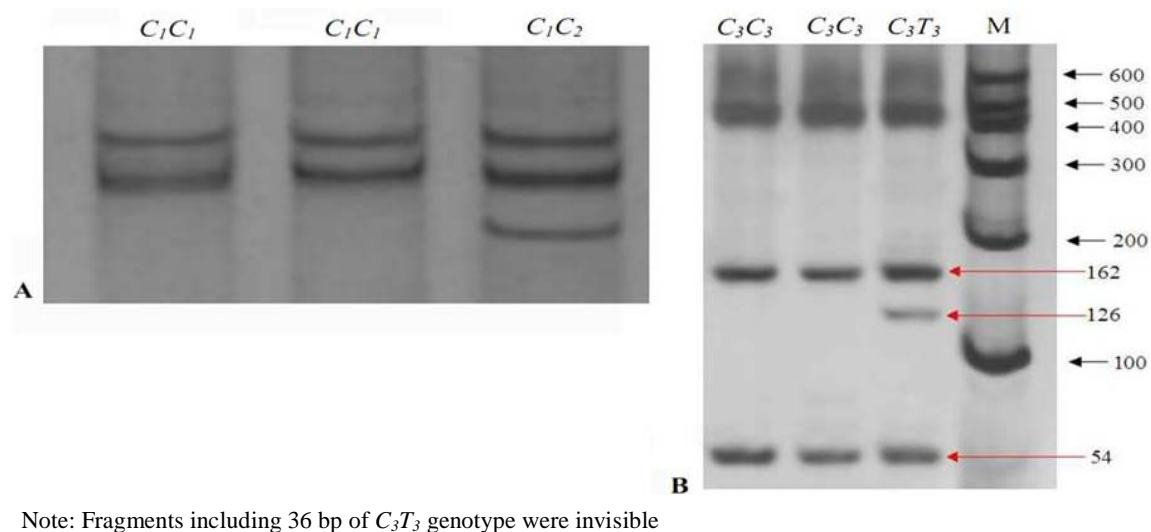

Figure 1. SNP detection of PCR products at g.407_408ins $C$ (A) and g.6852C $>T$ (B) loci for two goat breeds. 
intron 14 of DGAT1 gene (primer pair 1). Two base substitutions (g.6798C $>\mathrm{T}$ and g.6852C $>\mathrm{T}$, GenBank no. JN091564) were detected in PCR products of primer pair 2 (exon 7), which were synonymous mutations. Because there is no homozygote at the g.6798 C>T locus, relevant data are not listed in Figure and Table. At g.407_408insC locus, C1C1 and C1C2 genotypes were found in SN and GZ breeds (Figure 1A). At g.6852C $>\mathrm{T}$ locus, C3C3 and C3T3 genotypes were detected in both breeds (Figure 1B). Allelic frequencies, He, and PIC are shown in Table 2. We found that the additive effect of DGAT1 and STAT5A SNPs on milk yield and fat percentage was extremely significant $(\mathrm{P}<0.001)$, respectively. The additive effect between DGAT1 and STAT5A genes had extremely significant effects on milk fat percentage $(\mathrm{P}<0.001)$ (Table 3$)$.

\subsection{Association and Effects of the SNPs and Combination Genotypes}

In SN and GZ goat breeds, the genotypes of 528 individuals were analyzed for association with phenotypic data for milk yield and constituents at $g .407 \_408 i n s C$ and $g .6852 C>T$ loci (Table 4). Milk protein and lactose did not show any significant association with genotypes. At g.407_408ins $C$ locus, the does with $C_{1} C_{2}$ genotype had greater milk fat percentage than those with $C_{1} C_{1}$ genotype $(P<0.05)$. At $g .6852 C>T$ locus, the does with $C_{3} T_{3}$ genotype had greater milk yield than those with $C_{3} C_{3}$ genotype $(P<0.05)$ (Table 4). The does with $C_{1} C_{1} C_{3} T_{3}$ and $C_{1} C_{2} C_{3} T_{3}$ had higher milk yield than those with $C_{1} C_{2} C_{3} C_{3}$ $(P<0.05)$ (Table 5). In addition, the combined effect of $C_{1} C_{2} C_{3} T_{3}$ on milk fat percentage was the highest in comparison with other combination genotypes $(P<0.05)$.

\section{Discussion}

In this study, we analyzed the allelic frequencies of g.407_ 408ins $\mathrm{C}$ and g.6852C $>\mathrm{T}$ in two goat breeds ( $\mathrm{n}=528)$. The results showed that the $\mathrm{C}_{2}$ (g.407_408insC locus) and $\mathrm{T}_{3}$ (g.6852C>T) alleles had low frequencies (0.15-0.30), and $C_{2} C_{2}$

Table 2. Genotypic distributions, allelic frequencies of g.407_408ins $C$ and g.6852C $>T$ loci in two goat breeds.

\begin{tabular}{|c|c|c|c|c|}
\hline \multirow{2}{*}{\multicolumn{3}{|c|}{ Locus }} & \multicolumn{2}{|c|}{ Breed } \\
\hline & & & \multirow{2}{*}{$\begin{array}{c}\text { SN } \\
197\end{array}$} & \multirow{2}{*}{$\begin{array}{c}\text { GZ } \\
141\end{array}$} \\
\hline g.407_408insC & Genotype & $C_{1} C_{1}$ & & \\
\hline & & $C_{1} C_{2}$ & 88 & 102 \\
\hline & Allele & $C_{1}$ & 0.85 & 0.79 \\
\hline & & $C_{2}$ & 0.15 & 0.21 \\
\hline & & & 0.31 & 0.42 \\
\hline & & & 0.23 & 0.28 \\
\hline \multirow[t]{6}{*}{ g. $6852 C>T$} & Genotype & $C_{3} C_{3}$ & 112 & 106 \\
\hline & & $C_{3} T_{3}$ & 173 & 137 \\
\hline & & $C_{3}$ & 0.70 & 0.72 \\
\hline & Allele & $T_{3}$ & 0.30 & 0.28 \\
\hline & \multicolumn{2}{|c|}{$\mathrm{He}$} & 0.61 & 0.56 \\
\hline & \multicolumn{2}{|c|}{ PIC } & 0.33 & 0.32 \\
\hline
\end{tabular}

Table 3. The additive effect of $g .407 \_408 i n s C$ and $g .6852 C>T$ on milk yield $(\mathrm{kg})$ and fat percentage (\%).

\begin{tabular}{cccc}
\hline Locus & Effect & Milk yield & Milk fat percentage \\
\hline \multirow{2}{*}{ g.407_408ins $C$} & Additivet & $-1.58 \pm 4.93$ & $0.15 \pm 0.03$ \\
& $P$ value & 0.75 & $<0.001$ \\
g.6852 $C>T$ & Additivet & $18.78 \pm 10.08$ & $0.03 \pm 0.06$ \\
& $P$ value & $<0.001$ & 0.36 \\
g.407_408ins $C$ and g.6852 $C>T$ & Additivet $\times$ Additivet & $-7.80 \pm 2.36$ & $0.18 \pm 0.02$ \\
& $P$ value & 0.43 & $<0.001$ \\
\hline
\end{tabular}

Table 4. Association analysis of $g .407 \_408$ ins $C$ and $g .6852 C>T$ loci with milk yield $(\mathrm{kg})$ and constituents (\%) in goats (Xinong Saanen and Guanzhong goats).

\begin{tabular}{cccccc}
\hline Gene & Genotype & Milk yield (kg) & Milk fat (\%) & Milk protein (\%) & Lactose (\%) \\
\hline \multirow{2}{*}{ DGAT1 } & $C_{1} C_{1}(338)$ & $653.71 \pm 2.25$ & $3.38 \pm 0.03^{\mathrm{a}}$ & $2.97 \pm 0.01$ & $4.46 \pm 0.02$ \\
& $C_{1} C_{2}(190)$ & $660.29 \pm 3.25$ & $3.48 \pm 0.03^{\mathrm{b}}$ & $2.96 \pm 0.01$ & $4.45 \pm 0.02$ \\
\multirow{2}{*}{ STAT5A } & $C_{3} C_{3}(218)$ & $642.22 \pm 3.06^{\mathrm{a}}$ & $3.41 \pm 0.03$ & $2.97 \pm 0.01$ & $4.47 \pm 0.02$ \\
& $C_{3} T_{3}(310)$ & $665.67 \pm 2.48^{\mathrm{b}}$ & $3.45 \pm 0.03$ & $2.96 \pm 0.01$ & $4.45 \pm 0.01$ \\
\hline
\end{tabular}

Note: The data are expressed as least square means \pm standard errors. Values with different superscripts within the same column in particular population differ significantly at $P<0.05$. Numbers in brackets indicate the number of samples. Milk samples from third lactation have been analyzed for milk constituents. 
Table 5. Combined effects of DGAT1 and STAT5A genes on milk yield (kg) and fat percentage (\%) in goats (Xinong Saanen and Guanzhong goats).

\begin{tabular}{ccccc}
\hline Genotypic combination & Milk yield (kg) & Milk fat (\%) & Milk protein (\%) & Lactose (\%) \\
\hline$C_{1} C_{1} C_{3} C_{3}(147)$ & $642.10 \pm 3.65^{\mathrm{a}}$ & $3.44 \pm 0.03^{\mathrm{a}}$ & $2.96 \pm 0.01$ & $4.46 \pm 0.03$ \\
$C_{1} C_{1} C_{3} T_{3}(191)$ & $664.35 \pm 3.32^{\mathrm{b}}$ & $3.38 \pm 0.03^{\mathrm{a}}$ & $2.95 \pm 0.01$ & $4.42 \pm 0.02$ \\
$C_{1} C_{2} C_{3} C_{3}(70)$ & $645.23 \pm 5.48$ & $3.41 \pm 0.05^{\mathrm{a}}$ & $2.97 \pm 0.02$ & $4.45 \pm 0.04$ \\
$C_{1} C_{2} C_{3} T_{3}(120)$ & $666.21 \pm 3.89^{\mathrm{b}}$ & $3.59 \pm 0.04^{\mathrm{b}}$ & $2.93 \pm 0.01$ & $4.47 \pm 0.03$ \\
\hline
\end{tabular}

Note: The data are expressed as least square means \pm standard errors. Values with different superscripts within the same column in particular generation differ significantly at $P<0.05$. Numbers in brackets indicate the number of samples. Milk samples from third lactation have been analyzed for milk constituents.

(inset homozygote) and $T_{3} T_{3}$ (mutation homozygote) genotypes were not observed, respectively at the two loci in SN and GZ goat breeds. Flisikowski et al. (2003) reported $\mathrm{C} \rightarrow \mathrm{T}$ at position 6853 within the exon 7 of STAT5A gene and they found the TT genotype only in Polish native breeds (Polish Red and Polish White-Back cattle) [18]. We consider that the results can be explained by the following two reasons. (1) There is a lower frequency for missing genotypes, and the samples are small. (2) The missing genotypes of the two loci have negative effects on individual performance, so the individuals with missing genotypes have been eliminated in breeding process.

We firstly revealed the significant association of DGAT1 indel (g.407_408insC) and STAT5A SNP (g.6852C>T) with milk yield and fat percentage in Chinese dairy goats $(\mathrm{P}<0.05)$. Although the mutations of g.407_408ins C and g.6852C $>\mathrm{T}$ loci do not concern the coding region and the change of amino acid, they possibly influence the stability of the mRNA, and can affect the mechanism of mRNA deadenylation and degradation [19-21]. Linkage disequilibrium with the causal mutation possibly affects the variation of milk production traits in goat [22]. Previous studies have demonstrated the importance of DGAT1 and STAT5A genes in milk production traits in cattle $[7,8,23]$. DGAT1 candidate gene was found to have a significant effect not only on milk yield and component traits but also on the metabolism of intramuscular fat [7, 8, 24]. Amills et al. (2007) indicated $\mathrm{T}$ to $\mathrm{C}$ substitution at the intron 16 of goat DGAT1 gene could be used as a marker in association studies with milk traits [25]. Dario et al. (2009) studied the effect of STAT5A/ AvaI polymorphism on growth performance traits in Podolica bulls and suggested the superiority of $\mathrm{C}$ allele for growth performances because both $C C$ and $C T$ bulls tended to show a higher live weight and a faster growth in comparison with $T T$ animals [11]. Sadeghi et al. (2009) studied the association between this polymorphism of STAT5A gene and the breeding values of milk production traits in 134 Iranian Holstein bulls [26]. Dario et al. (2009) reported a substitution $C \rightarrow T$ at pos ition 6853 of STAT5A gene led to three genotypes (CC, CT and $C T$ ), and the cows with $C C$ genotype had higher milk yield and protein content than those with CT genotype [27]. The biochemical and physiological functions, together with the results obtained in our study, indicate that the DGAT1 and STAT5A genes might play important roles affecting milk production traits in goat. Genotypic value includes additive effect and dominant effect. Additive effect could be truly transmitted to offspring, so it is the focus of marker-assisted selection [28]. In this study, we took into account additive effect between SNP loci and milk production traits. The result showed the additive effect of g.407_408insC and g.6852C $>$ T on milk yield and fat percentage was extremely significant $(P<0.001)$, respectively. Compared with single SNP analysis, combination genotypes analysis provides more information on gene interactions. Multiple locus analysis used in the study revealed that the combined effect of DGAT1 g.407_408insC and STAT5A g.6852C>T significantly affected milk yield and fat percentage. Kong et al. (2007) indicated no significant effects on economic traits in Hanwoo cattle were found in the separate analysis of K232A and T11993C polymorphisms of DGAT1 gene, but the interaction between K232A and T11993C showed a significant effect $(P<0.005)$ on marbling score [24]. Based on the above considerations, we thought milk production traits were subjected to the impacts of g.407_408ins $C$ and g.6852 $C>T$ loci, and there was an interaction between both loci.

\section{Acknowledgements}

This study was supported by the National Support Program of China (2011BAD28B05-3) and Science and Technology Innovation Project of Shaanxi Province (2011KTCL02-09)

\section{REFERENCES}

[1] X.P. An, S.G. Song, J.X. Hou, C.M. Zhu, J.X. Peng, X.Q. Liu, et al., "Polymorphism identification in goat DGAT2 gene and association analysis with milk yield and fat percentage," Small Ruminant Research, vol. 100, pp. 107-112, 2011.

[2] J.C. Dekkers, "Commercial application of marker- and gene-assisted selection in livestock: strategies and lessons," Journal of Animal Science, vol. 82, pp. E313-328, 2004.

[3] I. Parmentier, D. Portetellea, N. Gengler, A. Prandic, C. Bertozzia, L. Vleuricka, et al., "Candidate gene markers associated with somatotropic axis and milk selection,” Domestic Animal Endocrinology, vol. 17, pp. 139-148, 1999.

[4] P. Hatzopoulos, G. Banilas, M. Karampelias, I. Makariti, and A. Kourti, "The olive DGAT2 gene is developmentally regulated and shares overlapping but distinct expression patterns with DGAT1,” Journal of Experimental Botany, val. 62, pp. 521-532, 2011.

[5] K. Giannoulia, K. Haralampidis, Z. Poghosyan, D.J. Murphy, and P. Hatzopoulos, "Differential expression of diacylglycerol acyltransferase (DGAT) genes in olive tissues," Biochemical Society Transactions, vol. 28, pp. 695-697, 2000.

[6] S. Cases, S.J. Stone, P. Zhou, E. Yen, B. Tow, K.D. Lardizabal, et al., "Cloning of DGAT2, a second mammalian diacylglycerol acyltransferase and related family members,” Journal of Biolog- 
ical Chemistry, vol. 276, pp. 38870-38876, 2001.

[7] B. Grisart, W. Coppieters, F. Farnir, L. Karim, C. Ford, P. Berzi, et al., "Positional candidate cloning of a QTL in dairy cattle: Identification of a missense mutation in the bovine DGAT1 gene with major effect on milk yield and composition," Genome Research, vol. 12, pp. 222-231, 2002.

[8] A. Winter, W. Kramer, F.A.O. Werner, S. Kollers, S. Kata, G. Durstewitz, et al., "Association of a lysine-232/alanine polymorphism in a bovine gene encoding acyl-CoA : diacylglycerol acyltransferase (DGAT1) with variation at a quantitative trait locus for milk fat content," Proceedings of the National Academy of Sciences, vol. 99, pp. 9300-9305, 2002.

[9] J.E. Darnell, I.M. Kerr, and G.R.Stark, "Jak-Stat pathways and transcriptional activation in response to IFNs and other extracellular signaling proteins,” Science, vol. 264, pp. 1415-1421, 1994.

[10] H. Wakao, F. Gouilleux, and B.Groner, "Mammary-gland factor (Mgf) is a novel member of the cytokine regulated transcription factor gene family and confers the prolactin response,” Embo Journal, vol. 13, pp. 2182-2191, 1994.

[11] C. Dario, M. Selvaggi, D. Carnicella, and G. Bufano, "STAT5A/AvaI polymorphism in Podolica bulls and its effect on growth performance traits," Livestock Science, vol. 123, pp. 83-87, 2009

[12] H.M. Seyfert, C. Pitra, L. Meyer, R.M. Brunner, T.T. Wheeler, A. Molenaar, et al., "Molecular characterization of STAT5A- and $S T A T 5 B$-encoding genes reveals extended intragenic sequence homogeneity in cattle and mouse and different degrees of divergent evolution of various domains," Journal of Molecular Evolution, vol. 50, pp. 550-561, 2000.

[13] A. Molenaar, T.T. Wheeler, J.Y. McCracken, and H.M. Seyfert, "The STAT3-encoding gene resides within the $40 \mathrm{kbp}$ gap between the STAT5A- and STAT5B-encoding genes in cattle," Animal Genetics, vol. 31, pp. 339-340, 2000

[14] E. Antoniou, B.J. Hirts, M. Grosz, and J. Skidmorec, "A single strand conformation polymorphism in the bovine gene STAT5A," Animal Genetics, vol. 30, pp. 225-244, 1999

[15] P. Brym, S. Kamiński, and A. Ruść, "New SSCP polymorphism within bovine STAT5A gene and its associations with milk performance traits in Black-and-White and Jersey cattle," Journal of Applied Genetics, vol. 45, pp. 445-452, 2004.

[16] R. Mullenbach, P.J. Lagoda, and C. Welter, "An efficient salt chloro-form extraction of DNA from blood and tissue," Trends in Genetics, vol. 5, pp. 391, 1989.

[17] X.P. An, J.G. Wang, J.X. Hou, H.B. Zhao, L. Bai, G. Li, et al., "Polymorphism identification in the goat MSTN gene and associ- ation analysis with growth traits," Czech Journal of Animal Science, vol. 56, pp. 529-535, 2011.

[18] K. Flisikowski, J. Oprzdek, E. Dymnicki, and L.Zwierzchowski, "New polymorphism in bovine STAT5A gene and its association with meat production traits in beef cattle," Animal Science Papers and Reports, vol. 21, pp. 147-157, 2003.

[19] D.R. Gallie, and T.E. Young, "The regulation of gene-expression in transformed maize aleurone and endosperm protoplasts-analysis of promoter activity, intron enhancement, and messenger-RNA untranslated regions on expression,” Plant Physiology, vol. 106, pp. 929-939, 1994.

[20] J.Q. Clement, S. Maiti, and M.F. Wilkinson, "Localization and stability of introns spliced from the Pem homeobox gene," Journal of Biological Chemistry, vol. 276, pp. 16919-16930, 2001.

[21] Z.E. Sauna, and C. Kimchi-Sarfaty, "Understanding the contribution of synonymous mutations to human disease," Nature Reviews Genetics, vol. 12, pp. 683-691, 2011.

[22] J.H.J. Van der Werf, K. Marshall, and S. Lee, "Methods and experimental designs for detection of QTL in sheep and goats," Small Ruminant Research, vol. 70, pp. 21-31, 2007.

[23] H. Khatib, R.L. Monson, V. Schutzkus, D.M. Kohl, G.J.M. Rosa, J.J. Rutledge, "Mutations in the STAT5A gene are associated with embryonic survival and milk composition in cattle," Journal of Dairy Science, vol. 91, pp. 784-793, 2008.

[24] H.S. Kong, J.D. Oh, J.H. Lee, D.H. Yoon, Y.H. Choi, B.W. Ch, et al., "Association of sequence variations in DGAT1 gene with economic traits in Hanwoo (Korea cattle)," Asian-Australasian Journal of Animal Sciences, vol. 20, pp. 817-820, 2007.

[25] M. Amills, A. Angiolillo, B. Urrutia, A. Domenech, Y. Sastre, B. Badaoui, et al., "Identification of a single nucleotide polymorphism at intron 16 of the caprine acyl-coenzyme A: Diacylglycerol acyltransferase 1 (DGAT1) gene,” Journal of Dairy Research, vol. 74, pp. 47-51, 2007.

[26] M. Sadeghi, M.M. Shahrbabak, G.R. Mianj, and A.N. Javaremi, "Polymorphism at locus of STAT5A and its association with breeding values of milk production traits in Iranian Holstein bulls," Livestock Science, vol. 123, pp. 97-100, 2009.

[27] C. Dario, M. Selvaggi, G. Normanno, G.V. Celano, and M. Dario, "Genetic polymorphism of STAT5A protein: relationships with" production traits and milk composition in Italian Brown cattle," Journal of Dairy Research, vol. 76, pp. 441-445, 2009.

[28] X.P. An, D. Han, J.X. Hou, G. Li, Y.N. Wang, L. Li, et al., "Polymorphism of exon 2 of $F S H \beta$ gene and its relationship with reproduction performance in two goat breeds," Agricultural Sciences in China, vol. 9, pp. 880-886, 2010. 